\title{
A onipresença do medo na influenza de 1918*
}

\section{Omnipotent fear along 1918 influenza}

Em memória da professora Dea Ribeiro Fenelon

LIANE MARIA BERTUCCI

Doutora em História pela Universidade Estadual de Campinas Professora de História da Educação no Departamento de Teoria e Fundamentos da Educação da Universidade Federal do Paraná Rua General Carneiro, $460,5^{\circ}$ andar, secretaria DTFE 80060-150 - Curitiba - PR - Brasil liane@ufpr.br

RESUMO O medo é um sentimento de diversas faces que durante a vigência de uma grave epidemia torna-se onipresente, podendo motivar tanto a discriminação e a exclusão, quanto a procura desesperada, e muitas vezes solidária, pela cura da doença. Moléstia que desafiou o saber médico-científico, a epidemia de influenza espanhola fez aflorar entre os brasileiros o medo do contato com o outro, a indiferença das pessoas e o temor ancestral dos hospitais. Mas, o medo da gripe de 1918 motivou também a solidariedade, expressa de maneira singular na divulgação de práticas caseiras de cura que, combinadas com esparsas informações médicas e com a fé, traduziram a generosidade de indivíduos que difundiam gratuitamente aquilo que, acreditavam, poderia acabar com a epidemia.

* Artigo recebido em: 19/03/2009. Autor convidado. 
Palavras-chave gripe espanhola, história social da cultura, medicina popular

ABSTRACT Fear is a multiple faces feeling that along a hard epidemic becomes omnipresent, as well as it can motivate discrimination and exclusion together to desperate, and many times solidary, search for disease cure. A disease that challenged medical-scientific knowledge, influenza epidemic brought up among Brazilians fear of personal contact, as well as people unconcerning and ancestral terror of hospitals. On the other hand, 1918 influenza fear motivated solidarity, which had been expressed in a singular manner on domestic healing practices that, joint together few medical information and faith, revealed generosity of individuals who broadcast for free those information that, they believed, could put an end to the epidemic.

Key words Spanish flu, social history of culture, popular medicine

\section{Introdução}

Em meados de 1918, os jornais brasileiros publicaram algumas notas sobre uma epidemia que grassava na Europa há algumas semanas. 0 pequeno destaque concedido à doença, que muitos já denominavam gripe espanhola ou influenza espanhola, era, em grande parte, resultado dos próprios comentários editados que, mesmo de maneira não conclusiva, afirmavam ser a moléstia apenas mais uma epidemia de gripe: doença microbiana, endêmica e mundial. Enfermidade que, durante três ou quatro dias, causava coriza, dores no corpo, tosse e um pouco de febre, em geral sem grandes complicações. Outras causas do pouco interesse pela nova epidemia era a grande atenção que mereciam as notícias sobre a guerra mundial e a carestia generalizada dos gêneros alimentícios em todo o Brasil, inclusive devido à exportação para países beligerantes. A mudança de atitude dos brasileiros em relação à gripe espanhola, a partir de meados de setembro, foi impulsionada por dois acontecimentos: a confirmação da existência de gripados e mortos pela doença entre os membros da Missão Médica Brasileira, que havia partido para a Europa e fizera parada em Dacar (Senegal), onde grassava a moléstia, e a publicação de informações, ainda que pouco detalhadas, sobre o navio Demerara que, vindo da Europa, havia feito escala em Recife, Salvador e Rio de Janeiro com passageiros enfermos. Alguns teriam desembarcado em terras brasileiras. Pouco a pouco, notícias sobre a existência de gripados nas cidades portuárias do Brasil foram ganhando as páginas dos jornais e, entre desmentidos e a determinação federal de vistoria sanitária em navios atracados no país, os gripados começaram a ser contados. ${ }^{1}$

1 BERTUCCI, Liane Maria. Influenza, a medicina enferma. Campinas: Ed.Unicamp, 2004, p.90-99. 
Em Salvador, dia 24 de setembro, cerca de 700 pessoas estavam com gripe. Três dias depois, em Recife (onde boatos já falavam da existência de gripados), eram internados em hospital da cidade, com suspeita da moléstia, alguns tripulantes de um navio brasileiro vindo de Dacar. Ao noticiar a chegada dos marinheiros, o jornal carioca O País apelou para a tranquilidade da população, afirmando não haver "motivo para alarmes". ${ }^{2}$ Discussões sobre a enfermidade se intensificaram e vários foram os que aventaram a hipótese de ser a gripe que começava a se alastrar pelo Brasil diferente da influenza espanhola, que vitimava outras partes do mundo. Nesse contexto, dia 8 de outubro, eram confirmados oficialmente os primeiros casos de gripe no Rio de Janeiro. Dois dias depois jornais denunciavam a presença da moléstia em Belo Horizonte, informação só confirmada pelas autoridades médicas locais depois de uma semana. ${ }^{3} \mathrm{Em}$ poucos dias, jornais de todo o país alertavam sobre a presença de gripados em diferentes partes do território nacional. ${ }^{4}$ Diminuiu rapidamente o número daqueles que acreditavam na diferença entre a gripe local e a de além-mar.

Em meio aos comentários sobre a doença, dia 10 de outubro, o doutor Carlos Seidl, então Diretor Geral de Saúde Pública (órgão do governo federal), em comunicado feito na Academia Brasileira de Medicina, no Rio de Janeiro, dizia que a influenza espanhola era a gripe comum na forma epidêmica; portanto moléstia extremamente contagiosa, inacessível às ações profiláticas internacionais, inclusive o isolamento. Apenas medidas de profilaxia individual eram recomendadas e teriam alguma eficiência: ingestão de sais de quinino, como preventivo, e a rigorosa anti-sepsia da boca e nariz. ${ }^{5}$ Menos de uma semana depois do comunicado feito por Seidl, declaração do doutor Arthur Neiva, diretor do Serviço Sanitário do Estado de São Paulo em 1918, afirmava que

não pode haver profilaxia eficaz, regional ou local para a influenza, toda ela deve ser individual. Para evitar a influenza todo indivíduo deve fugir das aglomerações,

2 SOUZA, Christiane Maria C. de. A gripe espanhola em Salvador, 1918: cidade de becos e cortiços. História, ciências, saúde - Manguinhos. Rio de Janeiro, v.12, n.1, p.71-99, jan-abr. 2005; O País. Apud: BRITO, Nara Azevedo de. La dansarina: a gripe espanhola e o cotidiano na cidade do Rio de Janeiro. História, ciências, saúde - Manguinhos. Rio de Janeiro, v.IV, n.1, p.11-30, mar-jun. 1997.

3 O País. Apud: BRITO, Nara Azevedo de. La dansarina: a gripe espanhola e o cotidiano na cidade do Rio de Janeiro, p.19; SILVEIRA, Anny Jackeline T. A influenza espanhola e a cidade planejada. Belo Horizonte: Argumentum, 2008, p.143-144.

4 As cidades portuárias foram as primeiras a registrarem a doença e, entre elas, as do nordeste e norte do Brasil tiveram primazia. A doença castigou toda a região a partir da chegada do Demerara, em 15 de setembro, no porto do Recife. Aproximadamente um mês depois de o navio aportar em Pernambuco, a gripe espanhola vitimava a região sudeste e sul, e cerca de um mês depois o Centro-Oeste do Brasil. No estado do Mato Grosso, com população dispersa e poucas vias de comunicação terrestre, o governo conseguiu isolar a capital e a região norte do estado instalando uma barreira sanitária no rio Paraguai, única via de acesso ao sul do país. A influenza espanhola só vitimou Campo Grande, rompendo o isolamento, em fins de novembro - eram doentes vindos de Corumbá. Cf.: MEYER, Carlos Luiz e TEIXEIRA, Joaquim Rebello. A grippe epidêmica no Brazil e especialmente em São Paulo. São Paulo: Casa Duprat, 1920.

5 Sessão de 10 de outubro de 1918. Boletim da Academia Nacional de Medicina, Rio de Janeiro, Typ. Jornal do Commercio, ano 89, p.591, 1918 
principalmente à noite; não freqüentar teatros, cinemas; não fazer visitas e tomar cuidados higiênicos com a mucosa nasofaringeana que, muito provavelmente, é a porta de entrada dos germens [da gripe]. ${ }^{6}$

Palavras que, se pretendiam tranquilizar a população, pouco efeito devem ter causado, pois a quantidade de doentes crescia apesar de muitos já seguirem as recomendações propostas. Nas páginas dos jornais os médicos começaram a repetir que era preciso respeitar a "marcha natural da moléstia", 7 isto é, as seis semanas que caracterizavam qualquer período epidêmico de gripe, a partir do primeiro caso da doença em uma região.

Mas a virulência da gripe epidêmica de 1918 era descomunal. No Rio de Janeiro, o número de doentes registrados saltou de 440, dia 10 de outubro, para cerca de 20 mil quatro dias depois. Apelos para ações médico-governamentais imediatas foram então combinados com frases que tentavam convencer a população a manter a calma, pois o pânico rondava e o descontrole parecia iminente. ${ }^{8}$ Artigo do jornal O País, do dia 17 de outubro, dizia que era necessário combater duas epidemias, a de gripe espanhola e a do medo, concluindo que, apesar da seriedade da situação, "não há motivo para essa atmosfera de injustificável pavor". ${ }^{9}$

Na cidade de São Paulo, a confirmação oficial da presença da moléstia aconteceu dia 15 de outubro. O primeiro caso da doença teria sido registrado dois dias antes: um estudante vindo do Rio de Janeiro que estava internado no Hospital de Isolamento da cidade. No dia seguinte ao anúncio, o jornal O Combate estampou a manchete: "A influenza espanhola. A terrível enfermidade faz a sua aparição em São Paulo". E, como no Rio de Janeiro, entre informações e comentários que imediatamente invadiram as páginas dos jornais, foram publicados pedidos para que os paulistanos mantivessem a calma. Texto publicado no jornal $A$ Capital dizia: "não há razão para pânico e, ainda que houvesse, tudo aconselharia a resistir-lhe. O terror nada adianta e nada modifica, senão para pior". O mesmo aconteceu em Belo Horizonte, onde jornais também apelaram à tranquilidade, mas com a advertência sobre os perigos da coragem descuidada. ${ }^{10}$

Desde a Idade Média, segundo Mirko Grmek, quando para cristãos e muçulmanos acontecimentos do corpo eram indissociáveis de significados espirituais, que sentimentos como o medo e o desânimo passaram a ser percebidos como fatores de desequilíbrio, de predisposição à doença e a

\footnotetext{
O Estado do S.Paulo, São Paulo, n.14.536, p.5, 16 out. 1918.

A Platéa, São Paulo, n.114, p.6, 22 out. 1918.

O País. Apud: BRITO, Nara Azevedo de. La dansarina, p.20-21.

O País. Apud: BRITO, Nara Azevedo de. La dansarina, p.20.

10 O Combate, São Paulo, n.1.028, p.1, 16 out. 1918; A Capital, São Paulo, n.132, p.1, 19 out. 1918; SILVEIRA, Anny Jackeline T. A influenza espanhola e a cidade planejada, p.261.
} 
sua propagação. ${ }^{11}$ A medicina medieval, fundamentada nas obras de Galeno (c.131-201), foi desenvolvida com base na teoria dos "quatro humores", de Hipócrates (c.460-377a.C) e de seu discípulo e genro Pólibo (ou Políbio). ${ }^{12}$ Teoria que foi combinada com as "quatro causas" aristotélicas. ${ }^{13}$ Essa tese humoral da saúde e doença, que associava equilíbrio dos humores (ou elementos) e boa ordem espiritual, resultou na Idade Média em uma medicina "psicossomática", como denominou Grmek, cujos desdobramentos atravessaram os séculos. Alguns de seus princípios estarão presentes mesmo entre aqueles que, notadamente desde o Renascimento, contestaram a tradição hipocrática, Galeno e Aristóteles. ${ }^{14}$

Crítico da teoria humoral, neoplatônico, estudioso das potencialidades curativas de metais e minerais preparados quimicamente, Paracelso (14931541) defendeu a tese que o homem reproduzia, em miniatura, o macrocosmo universal e proclamou que para cada doença haveria um remédio específico. ${ }^{15}$ Para ele, as causas das moléstias humanas se encontrariam em fatores externos que se introduziriam no corpo das pessoas através de alimentos, bebidas e, especialmente, através do ar. ${ }^{16}$ Ao escrever sobre a peste, Paracelso afirmou que a combinação entre a "semente" da enfermidade, que estaria no ar corrompido, se transformaria em doença ao ser combinada com o "fermento do pavor" presente nos indivíduos. ${ }^{17}$

Essa relação propagação de doença e medo, herança medieval, atualizada durante o Renascimento, embasou diversas obras escritas entre os séculos XIV e XVIII que tinham como tema as enfermidades epidêmicas. Informando diferentes ações de combate às doenças, esses textos escritos por médicos ensinavam que manter a alegria, permanecer em boa e pequena companhia, ouvir música, ler ou ouvir leitura agradável, poderia afastar a moléstia temida. E não apenas os doutores reproduziam a tese

11 LE GOFF, Jacques e TRUONG, Nicolas. Uma história do corpo na Idade Média. Rio de Janeiro: Civilização Brasileira, 2006, p.108.

12 No texto Da natureza do homem, Pólibo escreve que o corpo humano é constituído por sangue, fleuma, bile amarela e bile escura, e sua saúde depende do equilíbrio destes humores. Estes "quatro humores" correspondiam aos quatro elementos: fogo, terra, ar e água (e suas quatro qualidades: quente, frio, seco e úmido; as quais eram acrescentadas outros grupos de oposição: cru e cozido, amargo e doce). Uma tradição médica que lembrava a "boa mistura" (ou boas proporções) de Alcmeão de Cróton (c. 500 a.C.). Cf.: CAIRUS, Henrique (trad., intr., notas). Da natureza do homem. Corpus hippocraticum. História, ciências, saúde - Manguinhos, Rio de Janeiro, v.VI, n.2, p.395-430, julhooutubro de 1999; WATTS, Sheldon. Epidemias y poder. Barcelona: Editorial Andrés Bello, 2000, p.36-37.

13 Ao serem relacionadas à medicina, as "quatro causas" aristotélicas podem ser assim resumidas: causa eficiente, o ato médico ou o médico; causa material, o corpo; causa instrumental, qualquer instrumento ou meio terapêutico; causa final, o restabelecimento da saúde. Veja: LE GOFF, Jacques e TRUONG, Nicolas. Uma história do corpo na Idade Média, p.111.

14 Cf.: MOSSÉ, Claude. As lições de Hipócrates. In: LE GOFF, Jacques. (apres.) As doenças têm história. Lisboa: Terramar, s.d., p.39-55; PORTER, Roy. Das tripas coração. Rio de Janeiro: Record, 2004, p.41-53.

15 A tese remédio específico para enfermidade específica contrariava a medicina humoral, que não esperava dos remédios papel decisivo na cura, apenas que eles ajudassem o corpo a reencontrar seu equilíbrio natural, por exemplo, através da purgação ou suor. Cf.: PORTER, Roy. Das tripas coração, p.127.

16 DEBUS, Allen G. El hombre y la naturaleza em el Renascimiento. México D.C.: Fondo de Cultura Económica, 1996, p.49-73; PORTER, Roy. Das tripas coração, p.126; ROSSI, Paolo. O nascimento da ciência moderna na Europa. Bauru: Edusc, 2001, p.271-278.

17 DELUMEAU, Jean. História do medo no Ocidente. São Paulo: Companhia das Letras, 1990, p.125. 
"psicossomática", magistrados franceses, no século XVII, chegaram a ordenar divertimentos públicos para devolver a coragem aos moradores de Metz, assolada pela peste. ${ }^{18}$

Quando a epidemia de gripe espanhola tornou-se uma triste realidade para os brasileiros, apelos para que a população mantivesse a calma, afastasse o pânico ou o medo exagerado, atualizaram no início do século XX preceitos médicos de séculos anteriores, preceitos que podiam até ser condenados pela moderna medicina do novecentos, mas que estavam vivos na mentalidade dos homens da década de 1910.

\section{Medo: desespero, indiferença e isolamento}

Fazendo as populações abandonarem seus valores e costumes mais enraizados, a doença epidêmica interrompe atividades familiares, isola o doente, impõe o silêncio à cidade, o anonimato na morte, e determina a abolição dos ritos coletivos de alegria e de tristeza. ${ }^{19} \mathrm{Em} \mathrm{1918,} \mathrm{os} \mathrm{brasi-}$ leiros, de norte a sul do país, tiveram seu cotidiano modificado devido à gripe espanhola, e assistiram os locais públicos (como escolas, parques, teatros, cinemas, etc.) serem fechados; as reuniões noturnas, inclusive as religiosas, tornarem-se proibidas (a diferença de temperatura, dentro e fora desses locais já favoráveis à propagação da doença, poderia ser fatal para as pessoas e para a difusão da moléstia), e os enterros com acompanhamento a pé serem vedados. Visitas foram condenadas e beijos e abraços desaconselhados. Até mesmo cumprimentar as pessoas com aperto de mão passou a ser ato indesejado. ${ }^{20}$ Muitas foram as localidades que, de olho nas maiores cidades do país já vitimadas pela epidemia, determinaram preventivamente estas medidas. No Paraná, na segunda quinzena de outubro, o diretor do Serviço Sanitário proibiu os "enterros à mão, enquanto entender necessário a bem da saúde pública", e aconselhou os moradores de Curitiba a não se visitarem e a não frequentarem lugares onde pudesse haver aglomeração. Justificavam suas ações, a epidemia que grassava no Rio de Janeiro e as determinações dos Serviços Sanitários da capital federal e de São Paulo. ${ }^{21}$ Inútil, em poucos dias os curitibanos e muitos paranaenses, como inúmeros outros brasileiros, estavam gripados.

18 DELUMEAU, Jean. História do medo no Ocidente, p.125-127.

19 Cf.: DELUMEAU, Jean. História do medo no Ocidente, p. 123-125.

20 BERTUCCI, Liane Maria. Influenza, a medicina enferma, p.106-113; O País. Apud: BRITO, Nara Azevedo de. La dansarina, p.22-24. GOULART, Adriana da Costa. Revisitando a espanhola: a gripe pandêmica de 1918 no Rio de Janeiro. História, ciências, saúde - Manguinhos, Rio de Janeiro, v.12, n.1, p.132, janeiro-abril de 2005; SILVEIRA, Anny Jackeline T. A influenza espanhola e a cidade planejada, p.169, 203. Alguns indivíduos até diziam "não" às regras que eram estabelecidas, para desespero dos médicos e de autoridades governamentais que as haviam determinado fazia poucos dias. Era uma tentativa extrema dessas pessoas para manterem vivas as relações sociais que eram colocadas em xeque. Cf.: A Gazeta, São Paulo, n.3.828, p.1 e n.3.830, p.1, 17 e 19 out. 1918.

21 XAVIER, Valêncio. O mez da grippe e outros livros. São Paulo: Companhia das Letras, 2002, p.15, 18, 21. 
Como uma reação em cadeia, também os mortos pela gripe espanhola foram contabilizados em todo o Brasil: em Salvador a partir de 27 de setembro, no Rio de Janeiro a partir de 13 de outubro e, entre belo-horizontinos, paulistanos e porto-alegrenses, a partir de 21 de outubro. ${ }^{22} \mathrm{~A}$ vida das cidades foi ganhando o compasso da epidemia, com as pessoas mais e mais isoladas. Muitos tentaram fugir, mas para onde? Os que se evadiram das cidades saíram apressados, deixando para trás casa, emprego e, principalmente, parentes e amigos. Em Curitiba, coisa rara, uma família ainda teve tempo de pagar anúncio em jornal para tentar conseguir uma cozinheira que os acompanhasse "para o interior", mas, em geral, a pressa foi a regra, o que algumas vezes causou situações inusitadas: uma luz acesa em casa repentinamente silenciosa foi motivo para especulações assustadoras entre os paulistanos - estariam todos mortos? Em poucos dias as autoridades policiais explicaram que a família havia partido, tentando fugir da gripe espanhola, e esquecera-se de desligar a lâmpada. Mas, se fugir era difícil, e cada dia mais inútil devido às proporções da epidemia, o que muitas famílias fizeram foi se trancar em suas casas na tentativa de não contrair a moléstia. Várias delas escalaram apenas um de seus membros para sair à rua e, evitando o contato com muitas pessoas, fazer o mais rapidamente possível o estritamente necessário, como comprar comida. ${ }^{23}$

O aumento do número de enfermos e mortos gerou uma sensação de impotência que fez o medo crescer imensamente. A notícia, publicada dia 23 de outubro pelos jornais de São Paulo, da tentativa de suicídio de um operário ao supor estar com gripe espanhola, porque tinha dor de cabeça, dá uma noção do pavor que a doença estava despertando. Dois dias depois, artigo do jornal A Federação, de Porto Alegre, diagnosticava como causa de vários suicídios ocorridos na cidade "o pavor coletivo, o alarma social", motivado pela gripe espanhola. ${ }^{24}$

Os apelos para que a população mantivesse a calma continuaram, mas as tragédias que aconteceram no chamado "delírio da febre" multiplicaramse. ${ }^{25} \mathrm{Em}$ meio ao caos que parecia inevitável, texto do jornal Commercio do Paraná, explicitando atitude assumida por vários periódicos, declarava formalmente: "esta folha sempre se manteve numa atitude de calma solicitude ante os interesses públicos, abstendo-se de dar notícias que pudessem levar o terror à nossa população". ${ }^{26}$ Mas, historicamente, esse tipo de apelo

22 ABRÃO, Janete Silveira. Banalização da morte na cidade calada. Porto Alegre: EDIPUCRS, 1998, p.96; BERTUCCI Liane Maria. Influenza, a medicina enferma, p.110; O País. Apud: BRITO, Nara Azevedo de. La dansarina, p.25; SILVEIRA, Anny Jackeline T. A influenza espanhola e a cidade planejada, p.144; SOUZA, Christiane Maria C. de. A gripe espanhola em Salvador, 1918: cidade de becos e cortiços, p.92.

23 O Combate, São Paulo, n.1.065, p.1 e 3 e n.1.066, p.1, 4 e 5 dez. 1918; BOSI, Ecléa. Memória e sociedade. São Paulo: T.A.Queiroz Editor, 1983, p.225, 248; XAVIER, Valêncio. O mez da grippe e outros livros, p.41.

24 A Gazeta, São Paulo, n.3.833, p.4, 23 out.1918; ABRÃO, Janete Silveira. Banalização da morte na cidade calada, p.69.

25 Cf.: BERTUCCI, Liane Maria. Influenza, a medicina enferma, p.120-121.

26 Commercio do Paraná. Apud: XAVIER, Valêncio. O mez da grippe e outros livros, p.51. 
à calma, coragem e até ao 'bom humor', levou, muitas vezes, ao excesso e a libertinagem, como relataram Tucídides, Boccaccio e Defoe, ${ }^{27}$ para depois resultarem em prostração e indiferença, e foi o que ocorreu em 1918.

Homens e mulheres, aparentemente, desprovidos de sensibilidade e respeito, embrutecidos pelas proporções da epidemia de gripe espanhola, tornaram-se parte da triste realidade vivida pelos brasileiros durante a vigência da moléstia. Vários foram aqueles que procuraram tirar proveito financeiro com a doença, muitas vezes explorando vizinhos ou conhecidos: em Porto Alegre, até os vendedores de lenha majoraram o preço de seu produto; em São Paulo, pessoas solicitaram doações aos comerciantes da cidade, que, efetivamente, nunca seriam repassadas aos necessitados; também entre os paulistanos, alguns indivíduos, que haviam se comprometido a ajudar os médicos no atendimento aos gripados, extorquiram dinheiro de enfermos e seus familiares cobrando, sorrateiramente, pelos serviços prestados. Mas, poucas ocorrências traduziriam melhor o desrespeito e a insensibilidade que uma epidemia, de imensas proporções, pode acarretar do que a cena descrita pelo jornal O Estado de S.Paulo, de 17 de novembro: fazendo comentários irônicos, rindo dos olhares de pavor e censura das pessoas, um enfermeiro permanecia tranquilamente sentado sobre caixões de gripados mortos que eram conduzidos por uma carroça ao cemitério da Penha. ${ }^{28}$

Situações em que pontuavam acusações de indiferença e libertinagem também foram, pouco a pouco, ganhando as páginas dos periódicos. No início do mês de dezembro, a revista "independente" A Rolha, denunciou o serviço da Cruz Vermelha Brasileira no bairro do Brás, na capital paulista. Segundo a revista, os médicos "receitavam da porta, sem ver o gripado", e se dedicavam efetivamente ao "namoro e o deboche" com suas enfermeiras, banqueteando-se, embriagando-se, no almoço e no jantar, entregando-se "a bolina, aos beliscões, às apalpadelas". ${ }^{29}$ Utilizando palavras e imagens de impacto, o texto expunha mais um aspecto da realidade vivida pelas pessoas durante a influenza espanhola, um tempo em que muitos indivíduos desdenharam de suas obrigações e de seus semelhantes, tanto por prostração diante de uma doença que parecia incontrolável, quanto por medo da proximidade, do contato, com o outro, que poderia veicular a terrível doença.

27 Cf.: BOCCACCIO, Giovanni. Decamerão. São Paulo: Abril Cultural, 1971; DEFOE, Daniel. Um diário do ano da peste. Porto Alegre: L\&PM, 1987; TUCÍDIDES. História da Guerra do Peloponeso. $2^{a}$.ed. Brasília: Ed. UnB, 1982.

28 ABRÃO, Janete Silveira. Banalização da morte na cidade calada, p.70-71; A Capital, n.144, p.2, 6 nov.1918; O Estado de S.Paulo, n.14.568 e n.14.578, p.4-5, 17 e 27 nov. 1918.

29 A Rolha, n.38, p.13, 3 dez. 1918. Dia 28 de novembro, a Cruz Vermelha Brasileira havia publicado comunicado à população afirmando: "ao conhecimento da diretoria da Cruz Vermelha Brasileira tem chegado a notícia de abusos praticados por alguns dos seus auxiliares, cujos serviços foram aceitos durante a epidemia, ou por gente que, abusando dos distintivos dessa instituição, procurou ilaquear a boa fé de pessoas menos avisadas. Todos esses casos foram resolvidos com a dispensa dos acusados ou com queixa à polícia". A Platéa, São Paulo, n.149, p.6, 28 nov. 1918. 
Durante a gripe espanhola esse medo do contato/contágio foi evidenciado de várias formas, e 'o outro' tornou-se 'o inimigo', o emissário da morte, aquele que deveria ser evitado. Durante séculos, alguns grupos, religiosos ou não, como judeus e leprosos, foram apontados repetidamente como culpados por catástrofes epidêmicas, muitas vezes percebidas como castigo divino, uma punição pelos pecados, como informam Georges Duby e Jean Delumeau. ${ }^{30} \mathrm{Em}$ 1918, este medo ancestral ganhou novas características: não mais um grupo, mas todos eram potencialmente 'culpados' pela catástrofe epidêmica, qualquer pessoa poderia ser portadora da doença. A medicina bacteriológica, que popularizava informações sobre micro-organismos causadores de moléstias desde o final do século XIX, ${ }^{31}$ forneceu, indiretamente, argumentos científicos poderosos para que diversas pessoas sustentassem o pavor que despertava o contato/convívio com seus conterrâneos. As prescrições feitas pelos serviços médico-sanitários de diferentes partes do Brasil, para que fossem evitadas as aglomerações e contatos mais íntimos, como beijos e apertos de mão, bem como para que práticas higiênicas fossem intensificadas, descambaram entre muitos indivíduos para o medo exacerbado 'do outro'. Até roupas e sapatos usados, mesmo que devidamente limpos, causavam medo e repugnância. Um artigo publicado pela imprensa porto-alegrense, dia 4 de novembro, denunciava a peregrinação de compra realizada pelos donos de bricabraque que, carregados de mercadoria, percorriam vários bairros da cidade: "quantos micróbios ele [o comprador] vai espalhando e deixando nos lares onde bate, na esperança de ganhar umas migalhas?" O texto clamava a ação imediata das autoridades sanitárias. ${ }^{32}$

Esse medo do vizinho, do amigo ou do parente, que potencializou angústias e incertezas durante a influenza espanhola, teve um rival: o medo da hospitalização. Esporádica nos primeiros dias da epidemia, a justificativa médica para a internação hospitalar generalizada aconteceu quando o número de enfermos atingiu milhares e houve a constatação da diminuição progressiva daqueles que, com saúde, tinham os conhecimentos necessários para tratá-los. A hospitalização possibilitaria, segundo diziam, a concentração em lugares adequados tanto dos gripados quanto das pessoas que poderiam atendê-los. Poucas semanas separaram as campanhas para as internações hospitalares que foram realizadas nas maiores cidades do Brasil. A imprensa acompanhou a organização dos chamados "hospitais provisórios" para os "espanholados" e incentivou a

30 DUBY, Georges. Ano 1000 ano 2000: na pista de nossos medos. São Paulo: Ed.Unesp, 1998, p.87-89; DELUMEAU, Jean. História do medo no Ocidente, p.140-141. Veja: LE GOFF, Jacques e TRUONG, Nicolas. Uma história do corpo na Idade Média, p.105-108; WATTS, Sheldon. Epidemias y poder, p.79-81.

31 Entre outros, veja: BERTUCCI, Liane Maria. Saúde: arma revolucionária. São Paulo: 1891-1925. Campinas: Publicações CMU/Unicamp, 1997.

32 Gazeta do Povo. Apud: ABRÃO, Janete Silveira. Banalização da morte na cidade calada, p.78. 
medida médico-governamental. Em São Paulo, dia $1^{\circ}$ de novembro, texto do jornal O Estado de S.Paulo expressava preocupação com a "velha e arraigada prevenção do povo inculto contra hospitais". Dia 20 de dezembro, comentário publicado no jornal A Federação, de Porto Alegre, dizia que as pessoas "do povo [recusavam-se] com obstinação a aceitar os serviços hospitalares, por preconceito". ${ }^{33}$ Mas, o hospital, como afirmou Luc Boltanski, "regulamenta os contatos entre o doente e seus médicos, as famílias e o doente, aumenta a solidão e a ansiedade". ${ }^{34}$ Somava-se a isto o que a tradição, refeita cotidianamente entre a pessoas, ricas e pobres, informava sobre os nosocômios.

Em sua origem medieval, o hospital como conhecemos hoje, era, segundo alguns estudiosos (como Michel Foucault), tão somente um local onde morrer, entretanto, para outros pesquisadores (como Annie Saunier), este estabelecimento era o único local de cura e saúde para desprotegidos, sem teto, parentes ou dinheiro. Pessoas que só poderiam esperar auxílio da caridade pública. Caridade pública que, na Idade Média, se traduzia na instituição hospitalar. ${ }^{35}$ Assim, arraigado na memória como local de morte ou lugar privilegiado de tratamento dos desamparados, o hospital despertava receios e reservas de muitas pessoas. O ideal de assistência à pobreza, que norteou a organização das Santas Casas de Misericórdia, desde sua origem em Portugal, certamente contribuiu para a repulsa aos nosocômios em terras brasileiras: pouquíssimos eram os indivíduos que, de bom grado, aceitavam ser internados em locais historicamente organizados para acolher aqueles que não tinham nada e ninguém. ${ }^{36}$

Mas, apesar do medo, se não fossem hospitalizadas, que outra perspectiva restaria para pessoas que viam toda sua família adoecer, indivíduos que trabalhavam cerca de 12 horas por dia e recebiam salário que, muitas vezes, quando pagava o pão não pagava o aluguel? A hospitalização tinha um público privilegiado, os mais pobres das cidades, muitos deles operários; homens e mulheres que devido às péssimas condições sanitárias em que viviam, por falta de opção, e por seus hábitos pouco recomendáveis, segundo a moderna medicina, foram considerados 'o outro' por excelência

33 O Estado de S.Paulo, São Paulo, n.14.552, p.3, $1^{\circ}$ nov. 1918; A Federação. Apud: ABRÃO, Janete Silveira. Banalização da morte na cidade calada, p.125.

34 BOLTANSKI, Luc. As classes sociais e o corpo. 3ª.ed. Rio de Janeiro: Graal, 1989, p.43. Aumentavam ainda mais o medo dos hospitais: a falta de notícias sobre os internados; notícias de doentes supostamente enviados para o necrotério ou para o cemitério ainda com vida, e boatos sobre o chá da meia-noite: beberagem fatal que hipoteticamente os médicos dariam a doentes terminais para liberação de leitos. Cf.: BERTUCCI, Liane Maria. Influenza, a medicina enferma, p.128, 350-351.

35 Veja: FOUCAULT, Michel. O nascimento do hospital. In: Microfísica do poder. 4a .ed. Rio de Janeiro: Graal, 1984, p.99111; SAUNIER, Annie. A vida quotidiana nos hospitais da Idade Média. In: LE GOFF, Jacques (apres.). As doenças têm história. Lisboa: Terramar, s.d., p.205-220.

36 CORREIA, Fernando da Silva. Origens e formação das misericórdias portuguesas. Reedição. Lisboa: Livros Horizonte; Misericórdia de Lisboa, 1999; MESGRAVIS, Laima. A Santa Casa de Misericórdia de São Paulo (1599?-1884). São Paulo: Conselho Estadual de Cultura, 1976. 
durante a influenza espanhola. Mesmo o jornal paulistano "de oposição" O Combate apelou para a internação hospitalar desses indivíduos:

\begin{abstract}
A quase totalidade dos casos fatais [de gripe espanhola] se deram nos bairros habitados pela população proletária, especialmente, o Brás, o Bom Retiro, o Bexiga e a baixada que margeia as várzeas do Carmo e do Glicério. Este fato significa o que muitas vezes temos dito: o maior mal da "espanhola", já por si perigosa, é a falta de tratamento ocasionada pela demora dos médicos que assistem os enfermos necessitados e pela desorganização dos lares pobres, em que todos caem ao mesmo tempo e não há quem os acuda. O remédio, repetimos, está na hospitalização dos enfermos de formas mais graves e dos que se achem sem recursos pela generalização da moléstia. ${ }^{37}$
\end{abstract}

Entretanto, se em 1918 o medo, como em outros períodos epidêmicos, explicitou temores seculares, como o dos hospitais, e evidenciou a discriminação e o isolamento, o excesso e a indiferença das pessoas, esse sentimento onipresente mostrou também outros aspectos: o da solidariedade, marcada pela generosidade, e o da fé. Aspectos que se traduziram em diversas atitudes de homens e mulheres que tinham como objetivo divulgar meios que poderiam, acreditavam eles, acabar com a doença epidêmica, salvar a todos.

\title{
Medo: solidariedade e fé
}

Desde os primeiros casos confirmados de gripe espanhola no país, pessoas que não atuavam na área da saúde ou nos governos municipais, estaduais ou federal, ajudaram no combate à epidemia. ${ }^{38}$ Uma solidariedade diversificada que cresceu em todo o Brasil com o aumento do número de enfermos e mortos devido à gripe espanhola. Variados foram os auxílios prestados: o socorro individual a "espanholados" e seus familiares; o empréstimo de locais para atendimento aos gripados; a distribuição de comida aos necessitados; a realização de donativos as entidades que organizavam socorro aos doentes (como a Cruz Vermelha Brasileira e as cúrias metropolitanas). Grupos civis se mobilizaram: jornais organizaram comissões de auxílio; clubes de futebol, empresas, igrejas, ordens religiosas e várias associações e ligas, cederam espaço físico para socorrer as vítimas da influenza espanhola. Muitos ajudaram a angariar e a distribuir remédios e alimentos.

37 O Combate, n.1.042, p.3, $1^{\circ}$ nov. 1918.

38 Como exemplo da ação estatal durante a epidemia de gripe espanhola em diferentes pontos do Brasil, veja: BERTUCCI, Liane Maria. Influenza, a medicina enferma, p.101-133, 288-312; ABRÃO, Janete Silveira. Banalização da morte na cidade calada, p.95-116. Os profissionais da área de saúde, ligados aos governos ou não, atuaram efetivamente em todo o país. 
Em Salvador, nos primeiros dias da epidemia, o abade do Mosteiro de São Bento ofereceu as instalações do Mosteirinho de Mont Serrat para abrigar os gripados, e a Compagnie Chemins de Fer Federaux de L'Est Brésilien prestou socorro médico aos seus trabalhadores acometidos pela influenza espanhola. Em Porto Alegre, a Maçonaria Rio-Grandense, assim como outras associações, ofereceu suas instalações para tratamento dos gripados, e uma comissão da Federação Operária do Rio Grande do Sul percorreu o comércio local solicitando doações para os enfermos, cujo número crescia rapidamente. Em São Paulo e Belo Horizonte, durante várias semanas, os jornais não apenas informaram à população sobre as vítimas da epidemia, as doações feitas aos doentes ou os locais de atendimento aos gripados; vários periódicos também se prontificaram a receber donativos em suas sedes para repassá-los àqueles que socorriam os enfermos. Na capital paulista, a Comissão de Socorro Estado-Fanfulla, criada com esta finalidade, também organizou a distribuição de alimentos aos necessitados. ${ }^{39}$

Nos últimos dias de outubro, com a multiplicação de vítimas da influenza espanhola, artigo contundente do jornal O Estado de S.Paulo tentava mobilizar os paulistanos, notadamente os mais abastados, apelando para o medo que a doença despertava:

Urge, pois, que todas as pessoas generosas se prontifiquem a dar o que puderem. Note-se, mais uma vez, que não vai nisto um simples movimento de filantropia, mas também de defesa própria. É interesse de todos os habitantes da cidade que haja dentro desta quanto menos miséria, desocupação, orfandade e doença. ${ }^{40}$

E, espontânea ou induzida, a solidariedade marcou o tempo da gripe espanhola no Brasil, traduzindo um outro aspecto de um sentimento de várias faces: o medo. Uma das expressões desta solidariedade pode ser detectada na intensa divulgação de 'fórmulas caseiras' com a explicita intenção de, gratuitamente, ajudar as pessoas a curar a doença ou evitá-la.

Difundidas por todo o Brasil em 1918, as práticas de cura da medicina popular revelavam aspecto significativo do dinâmico universo cultural nacional. Eram fórmulas ou receitas tradicionais que concorriam para a maneira das pessoas perceberem e se relacionarem com o próprio corpo, com o mundo e, até mesmo, com a moderna ciência médica. Criando novos sentimentos e usos para elementos culturais herdados, este dinamismo, expresso em permutas e recriações, não traduzia ignorância, atraso ou indiferenciação de grupos sociais, mas assinalava a vitalidade da própria

39 SOUZA, Christiane Maria C. de. A gripe espanhola em Salvador, 1918: cidade de becos e cortiços, p.91; ABRÃO, Janete Silveira. Banalização da morte na cidade calada, p.112-113; BERTUCCI, Liane Maria. Influenza, a medicina enferma, p.123; SILVEIRA, Anny Jackeline T. A influenza espanhola e a cidade planejada, p.180.

40 O Estado de S.Paulo, São Paulo, n.14.547, p.3, 27 out.1918. 
cultura - entendida como o conjunto de valores, crenças e práticas diversas de uma sociedade que estão em permanente transformação. ${ }^{41}$

Exemplar foi uma das prescrições do uso do alho e da cebola para combater a influenza espanhola, publicada por um morador da Penha nas páginas dos jornais de São Paulo. O tradicional 'remédio' familiar, usado com sucesso por gerações contra a gripe, era chancelado, segundo o morador da capital paulista, por informações obtidas por ele em uma "revista científica". Na publicação consultada, cujo título não foi mencionado, um artigo informava que o alho e a cebola continham sulfureto, uma substância volátil, microbicida e cicatrizante, o que, para o paulistano, garantiria a ação dos vegetais na prevenção e cura da gripe, espanhola ou não. Ciência e prática caseira eram explicitamente combinadas nas palavras do morador de São Paulo que, generosamente, ensinava seu remédio contra a epidemia. ${ }^{42}$

Utilizados tradicionalmente na sociedade brasileira para combater a gripe de todos os anos, o alho, a cebola e, principalmente, o limão foram fartamente usados e recomendados por várias pessoas durante a influenza espanhola. Em Curitiba, os donos de várias fábricas da cidade chegaram a distribuir, diariamente, o suco da fruta em garrafas aos seus operários, na tentativa de barrar a expansão da epidemia. Intensa também foi utilização do alho e da cebola. Em São Paulo, comer um dente de alho durante as refeições, carregar um patuá de alho para cheirar constantemente, ou pendurar alho em volta do pescoço, para inalar suas substâncias desodorantes, foram prescrições ensinadas de boca-em-boca. Mas, não só de indicações locais se valiam os adeptos das fórmulas vegetais mais tradicionais. Artigos publicados em Porto Alegre, pelo jornal Correio do Povo, e em Belo Horizonte, pelo jornal Minas Gerais, respectivamente dias 6 e 7 de novembro, transcreveram notícia de periódico francês sobre o efeito curativo do suco de cebola sorvido pelo nariz pelos gripados. ${ }^{43}$

Na história da humanidade comida e temperos foram constantemente associados à saúde, sua manutenção e restauração, como mostraram os trabalhos de Jean-Louis Flandrin e de Innocenzo Mazzini. ${ }^{44}$ Associação que no Ocidente atravessou gerações amparada tanto pela medicina humoral, pois aquilo que se ingeria poderia concorrer ou não para o equilíbrio, e saúde, do organismo, quanto pelos que afirmavam que as doenças, resultados

41 Cf.: CHARTIER, Roger. A história cultural. Lisboa: DIFEL, 1990, p.121-139; GINZBURG, Carlo. O queijo e os vermes. São Paulo: Companhia das Letras, 1993; THOMPSON, Edward P. Costumes em comum. São Paulo: Companhia das Letras, 1998.

42 A Platéa, São Paulo, n.116, p.2, 24 out. 1918; A Capital, São Paulo, n.137, p.3, 25 out. 1918

43 XAVIER, Valêncio. O mez da grippe e outros livros, p.26; BOSI, Ecléa. Memória e sociedade, p.225; ABRÃO, Janete Silveira. Banalização da morte na cidade calada. A hespanhola em Porto Alegre, 1918, p.88; SILVEIRA, Anny Jackeline T. A influenza espanhola e a cidade planejada, p.203.

44 FLANDRIN, Jean-Louis. Tempero, cozinha e dietética nos séculos XIV, XV e XVI. In: FLANDRIN, Jean-Louis e MONTANARI, Massimo. História da Alimentação. São Paulo: Estação Liberdade, 1998, p.478-495; MAZZINI, Innocenzo. A alimentação e a medicina no mundo antigo. In: FLANDRIN, Jean-Louis e MONTANARI, Massimo. História da Alimentação, p.254-265. 
de fatores externos, poderiam se introduzir no corpo pelo que era ingerido pelo homem, como lembrava Paracelso. E essa proximidade entre a cozinha e o consultório médico, ou o laboratório, mesmo parecendo distante no século XX, ainda podia ser percebida durante o Novecentos na importância de vários produtos que, com seus nomes científicos, faziam parte da terapêutica médica. Exemplo significativo é o ácido cítrico, substância abundante no limão e amplamente utilizada pelos doutores. ${ }^{45}$ Mas eram nas práticas populares de cura que comida, temperos e outros vegetais continuavam tendo utilização abundante e diversificada.

No Brasil, durante a epidemia de influenza espanhola, a divulgação do uso de vegetais como remédios extrapolou as conversas caseiras e as trocas 'entre comadres', ganhando grande difusão pelos jornais. Presente na memória dos brasileiros, parte da tradição familiar, em 1918 essas 'receitas' foram combinadas com princípios médico-científicos e sua publicação expressou a solidariedade de muitas pessoas. ${ }^{46} \mathrm{Em}$ novembro, o jornal paulistano A Platéa publicou carta do senhor João de Escobar, morador do estado do Rio de Janeiro. Sensibilizado com a situação aflitiva, especialmente dos mais pobres, ele compartilhava a receita que utilizava para combater a influenza espanhola. Tudo muito simples: assar e chupar a fruta madura do gravatá e tomar chá de carqueja, os resultados, dizia, eram imediatos. Simplicidade também foi marca do 'remédio' que, generosamente, um padre de Curitiba ofereceu de casa em casa: folhas de eucalipto, que deveriam ser queimadas dentro das residências para limpar o ar e afastar a gripe espanhola. ${ }^{47}$ Desinfetar o ar, eliminando os micróbios da doença, foi uma obsessão nacional, e substâncias minerais foram associadas aos vegetais nesta empreitada. Queimar enxofre, que podia ser facilmente adquirido nas farmácias, foi fórmula difundida entre os paulistanos; entre os cariocas, usar incenso ou alcatrão e alfazema foi prática recomendada até por doutor. ${ }^{48}$

O conhecimento médico-científico que se firmou a partir do século XVIII, questionador de teses universalistas sobre o corpo humano, ${ }^{49}$ foi marcado em suas ações de combate às doenças e pela manutenção da saúde pela disputa entre duas correntes de pensamento: a dos infeccionista e a dos

45 BERTUCCI, Liane Maria. Influenza, a medicina enferma, p.220-223.

46 Muitas pessoas também apelaram para hipotéticas promessas na tentativa vender diversos produtos aos incautos. Outros indivíduos ganharam dinheiro industrializando e comercializando 'fórmulas caseiras', como, por exemplo, canela em pastilhas.

47 A Platéa, São Paulo, n.135, p.1, 12 nov.1918; XAVIER, Valêncio. O mez da grippe e outros livros, p.29.

48 BOSI, Ecléa. Memória e sociedade, p.248; O País. Apud: BRITO, Nara Azevedo de. La dansarina, p.21.

49 A revolução científica do século XVII transformou a percepção ocidental sobre o corpo. O corpo humano, até então visto como parte de uma ordem, de um equilíbrio, universal (oculto e/ou sagrado), era objeto de estudo há milênios e, mesmo no período renascentista, esses estudos eram feitos com base em sistemas de semelhanças, analogias e similitudes. Foram as observações científicas do Seiscentos que romperam com esta tese e as análises passaram a ser calcadas na precisão, distinção, transparência de método, certeza ou probabilidades, transformando a percepção do corpo humano, desvinculando-o de um sistema universalista e religioso - não por acaso a tese de uma 'força vital' humana, diferente da alma, ganhou destaque no século XVIII. Cf.: CZERESNIA, Dina. Do contágio à transmissão. Rio de Janeiro: Ed. Fiocruz, 1997, p.21-32. 
contagionistas. Calcadas, ao mesmo tempo, em princípios seculares e em um tipo de observação sobre o homem inaugurada havia poucas décadas, as duas teses, ancoradas em discussões sobre as epidemias, impulsionaram práticas na área da saúde até meados do século XIX. A teoria da infecção ou miasmática, tributária da escola hipocrática, afirmava a importância do estado do ar, e sustentava que as condições sanitárias ruins de uma região, as emanações que provocavam (percebidas imediatamente pelo olfato), poderiam arruinar a atmosfera local, causando enfermindades e o surgimento de doenças epidêmicas. Para os partidários da tese do contágio (defensores da quarenta, uma criação medieval), agentes específicos causariam as doenças; minúsculos "seres" que poderiam passar do indivíduo doente para outros e ocasionar epidemias. Estas duas concepções sobre a existência e propagação das doenças nem sempre foram conflitantes e suas práticas, como limpeza dos lugares e isolamento de doentes, formam muitas vezes combinadas. ${ }^{50}$ Alguns eminentes pesquisadores, como o infeccionista Max von Pettenkofer (1818-1901), aceitavam a possibilidade da existência e propagação de agentes específicos de doenças, desde que combinados com outros elementos, tais como, as condições do ar, do solo e os fatores sociais. Os estudos de Louis Pasteur, Robert Koch e seus colegas impulsionaram, a partir de meados do Novecentos, uma reviravolta na disputa entre as duas teses; mudaram os rumos da ciência médica ao reordenarem o entendimento que se tinha sobre os minúsculos seres observados sob o microscópio desde o século XVII, demonstrando sua existência em toda parte, liquidando a tese da geração espontânea, isolando microscópicos causadores de enfermidades. ${ }^{51} \mathrm{~A}$ partir de então, diferentes práticas infeccionistas foram subjugadas às orientações daqueles que dominavam o conhecimento sobre micro-organismos. A possibilidade de proliferação de micróbios causadores de enfermidades concorreu para a insistência dos bacteriologistas na importância da limpeza dos lugares, na livre circulação do ar e da água, uma resignificação de práticas miasmáticas.

Esse amalgamar de tradições também foi feito ao longo dos anos, de maneira muito particular, entre os chamados leigos, o que ficou evidente durante a gripe espanhola. Eram ideias miasmáticas e bacteriológicas que estavam na base dos argumentos usados por moradores do bairro

50 Até meados do século XIX, a teoria que dominou o meio científico ocidental foi a miasmática, quer pela dificuldade dos contagionistas em definir as intervenções específicas que deveriam ser feitas quando detectado o "ser" da doença, quer pela ascensão do liberalismo que forneceu argumento poderoso para os que percebiam o isolamento (individual ou coletivo) como algo desnecessário no combate à muitas enfermidades, um verdadeiro atentado a liberdade individual. Os ingleses, senhores do livre-comércio, foram fervorosos defensores da teoria miasmática que, se impulsionou significativos inventários e ações médico-governamentais nas cidades industriais modernas, também forneceu base científica para a luta pela franquia permanente dos portos do mundo.

51 Cf.: ACKERKNECHT, Erwin H. Anticontagionism between 1821 and 1867. Bulletin of the History of Medicine, n.22, p.562-593, 1948; CORBIN, Alain. Saberes e odores. São Paulo: Companhia das Letras, 1987; ROSEN, George. Uma história da saúde pública. São Paulo: Ed. Unesp, 1994, p.62-64 e 222-260; SOLOMON-BAYET, Claire. (org.) Pasteur et la revolution pasteurianner. Paris: Payot, 1986. 
da Barra Funda, em São Paulo, quando solicitaram a desativação de um hospital para gripados. Eles alegavam que os enfermeiros que trabalhavam no improvisado nosocômio despejavam as fezes dos internos em buracos abertos nos fundos do hospital, o que, segundo as pessoas do lugar, "predispunha o ambiente" a propagação da influenza espanhola, pois o lugar estava se transformando em um "antro de micróbios". ${ }^{52}$ Em Curitiba, moradores das imediações da rua Silva Jardim foram aos jornais denunciar e pedir providências: existia naquela rua uma casa onde mulheres lavavam roupas de um hospital de gripados. As peças lavadas eram perduradas em cercas, a água das roupas escorria pela rua formando poças, o que poderia colocar em risco a saúde de toda a vizinhança. ${ }^{53}$ Água estagnada já causava problemas, imagine se a água fosse proveniente da lavagem de roupas de "espanholados"!

E essas combinações feitas pelas pessoas, que amalgamavam diversos princípios científicos, misturando-os muitas vezes com práticas populares de cura, eram também permeadas pela religiosidade, como ficou evidente durante a epidemia de 1918.

Nas menores vilas e nas maiores cidades do Brasil, os vegetais tidos como medicamentosos eram vendidos nas ruas, mercados ou lojas especializadas, e sua utilização e comercialização era comumente associada a amuletos, orações, figas, cruzes, etc, que garantiriam ou potencializariam sua eficácia. Uma associação que expressava as diferentes tradições de cura existentes no país, que, vindas da Europa, praticadas pelos indígenas ou importadas com os africanos, estavam fortemente marcadas por valores religiosos.

Exemplo do que ocorria em todo o território nacional, na cidade de São Paulo da década de 1910 eram vários os locais que vendiam esses produtos. Grandes lojas nas ruas General Carneiro, Santa Efigênia e Conselheiro Crispiniano; pequenos cômodos do Mercado Municipal, ou bancas entre os pedestres que circulavam pelo Largo do Arouche. Muitos chás, como os de erva tostão, para doenças do fígado e dos rins, e o das cinco folhas, que combatia a gonorréia e doenças da bexiga e do útero. Para a vitalidade, o Guaraná dos índios Maués; para acabar com a tosse e as dores do peito, balas de limão bravo e de mel da abelha jataí. Para liquidar ou prevenir inúmeras doenças do corpo e da alma, defumações completas, figas de arruda e guiné, e diversas orações que, impressas, os crentes também poderiam encontrar nesses lugares. ${ }^{54}$

52 A Platéa, São Paulo, n.123, p.6, 31 out.1918.

53 XAVIER, Valêncio. O mez da grippe e outros livros, p.60.

54 Cf.: BERTUCCI, Liane Maria. Influenza, a medicina enferma, p.230-231. 
Em meio as muitas combinações dessas diferentes tradições, o catolicismo, permeado pelas crenças populares, criou raízes profundas, ${ }^{55}$ e a associação entre fé, saúde e doença se explicitou especialmente no apelo à intercessão dos santos para acabar com as moléstias, notadamente as epidêmicas.

As tábuas votivas ou ex-votos, uma herança portuguesa, eram uma das expressões populares de agradecimento aos santos. Presentes em diversas igrejas brasileiras, estas singelas pinturas sobre madeira, que lembravam uma moléstia ou pedido e a graça alcançada, eram o cumprimento de uma promessa feita ao santo da devoção..$^{56}$ Essa prática era resultado de transformações religiosas que remontavam a Europa do século XV, quando santos poderosos foram identificados às doenças que mais se temiam. Estes santos protegeriam da enfermidade ou concorreriam para a doença - uma punição dos pecadores. ${ }^{57} \mathrm{~A}$ terrível peste bubônica era então conhecida como o mal de São Sebastião ou de São Roque, crença que atravessou os mares e chegou ao Novo Mundo com os colonizadores lusitanos, ganhando vários significados ao se espalhar por uma sociedade de muitas raças. No Brasil, onde São Sebastião foi identificado como o grande advogado contra as catástrofes epidêmicas, as chamadas "pestes", 58 a crença em santos que poderiam interceder por benesses ou pelos castigos possibilitou a associação de alguns deles com divindades africanas. Omolu, orixá que protegia da varíola ou espalhava a doença, foi associado a São Benedito, santo negro muito popular entre escravos e libertos..$^{59}$

No início do século XX, a religiosidade continuava intermediando ações dos brasileiros em casos de doenças. Durante o período desesperador da gripe espanhola a fé foi o lenitivo de muitos, e vários foram os que recorreram à intervenção divina conclamando seus conterrâneos a fazer o mesmo. Assim, apesar dos apelos para que fossem evitadas aglomerações e de muitas igrejas fecharem suas portas ou reduzirem suas atividades, a crença no poder de cura, representado pela devoção, se manifestou de maneira coletiva em todo o Brasil. Em Curitiba, no final de outubro, antes mesmo de a doença fazer vítimas na cidade, missas na catedral eram celebradas

55 Cf.: WISSENBACH, Maria Cristina C. Ritos de magia e sobrevivência. Sociabilidades e práticas mágico-religiosas no Brasil (1890-1940). São Paulo: USP, 1997. (Tese, doutorado em História).

56 Cf.: CASTRO, Márcia de Moura. Ex-votos mineiros. As tábuas votivas no ciclo do ouro. Rio de Janeiro: Expressão e Cultura, 1994. Eram comuns em todo o Brasil, além das tábuas votivas, os objetos de cera ou outros materiais oferecidos em agradecimento pela graça alcançada, como a cura de uma doença, o salvamento de um naufrágio ou de um incêndio. Para Philippe Ariès, ao contrário de Castro, ex-votos são apenas as tábuas votivas, que aparecem na Europa entre o final do século XVI e início do XVII. O costume de, em agradecimento, reproduzir objetos ou partes do corpo era muito antigo, anterior a era cristã. Cf.: ARIĖS, Philippe. O homem diante da morte. Rio de Janeiro: Francisco Alves, 1989, v.l, p.303.

57 DELUMEAU, Jean. História do medo no Ocidente, p.71-149; THOMAS, Keith. Religião e declínio da magia. São Paulo: Companhia das Letras, 1991, p.36-38.

58 Cf. KRUG, Edmundo. Deus e os santos na superstição brasileira. Revista do Instituto Histórico e Geographico de São Paulo. São Paulo, v.XXIII (1925), p.168, 1927

59 CHALHOUB, Sidney. Cidade febril. São Paulo: Companhia das Letras, 1996, p.134-151. KARASCHI, Mary. A vida dos escravos no Rio de Janeiro, 1808-1850. São Paulo: Companhia das Letras, 2000, p.370-375. 
em louvor a São Sebastião e São Roque rogando a intervenção dos santos para que a capital paranaense fosse poupada da influenza espanhola. No mesmo período, no Recife, orações eram oferecidas a São Sebastião, na igreja de Nossa Senhora do Terço, pelo fim da "terrível moléstia", e em São Paulo, a capelinha do Bom Jesus do Monte, no Carandiru, passou a ficar aberta diariamente para que os "verdadeiros crentes" pudessem fazer suas preces ao glorioso São Sebastião. No Rio de Janeiro, a cidade do santo, as orações ao padroeiro eram redobradas, e quando o grande medo começou a passar, apesar da gripe espanhola ainda fazer vítimas na cidade, procissões foram feitas percorrendo as ruas da localidade ainda traumatizada pela calamidade epidêmica. ${ }^{60}$ "Remédio para toda a cidade, a procissão é uma súplica de toda a cidade", lembra Jean Delumeau. ${ }^{61}$

Mas não foram apenas os católicos que suplicaram aos céus pela saúde, pela salvação de todos. A Associação dos Pastores Evangélicos de São Paulo, reunida dia 28 de outubro, tomou a resolução de recomendar com insistência: "a todos os crentes evangélicos, que elevem, todos os dias ao meio-dia em ponto e onde quer que estejam, súplicas em favor dos indivíduos e famílias de seu conhecimento que se achem em aflição nesta capital e em todo o Brasil, devido às dificuldades atuais". ${ }^{62}$

Súplica individual, mas que conclamava a totalidade dos leitores do jornal em que foi publicada, fez um cidadão paulistano também no final de outubro. Aterrorizado pelas proporções da epidemia de influenza espanhola, o morador da cidade publicou um texto no jornal A Gazeta que começava com a frase: "Fatalidade, desídia dos homens, castigo de Deus?" Depois da pergunta objetiva e perturbadora, e de breve descrição da doença epidêmica, o autor do artigo, sem meias palavras, apontava os culpados pela calamidade: os pecadores (e neste caso católicos e protestantes concordavam) ${ }^{63}$ Reeditando culpados seculares, mas sem desconsiderar as ações que estavam sendo empreendidas por médicos, governos e particulares, o texto conclamava os homens a se voltarem para Deus e rogarem sua intercessão, para que "um sol radiante brilhe sempre nos altos e faça, ele só, o papel de grande microbicida que é. Que lave a terra das impurezas que a infestam, que nos traga envolto em seus raios alourados a purificação mesma da vida, sem epidemias e enfermidades". Conhecimento científico e fé, crenças tradicionais e medo milenar, uma combinação singular era feita, subjugando o saber da ciência ao poder da fé. O autor do texto concluía:

60 XAVIER, Valêncio. O mez da grippe e outros livros, p.31; O Estado de S.Paulo, São Paulo, n.14.536, p.4 e n.14.541, p.4 e 5, 16 e 21 out. 1918; Diario Popular, São Paulo, n.11.739, p.4, 23 out. 1918.

61 DELUMEAU, Jean. História do medo no Ocidente, p.148.

62 O Estado de S.Paulo, São Paulo, n.14.549, p.4, 29 out. 1918

63 Confira sobre o tema: DELUMEAU, Jean. História do medo no Ocidente, p.144-147; THOMAS, Keith. Religião e declínio da magia, p.82-83. 
Deus, Deus! Para a vossa misericórdia se voltam os homens. Quando o perigo ameaça, o espírito o mais indiferente, a alma a mais incrédula se dirige para a vossa força e para o vosso poder. Erguem-se as preces a vossa Bondade. Invocam-se as vossas bênçãos, pede-se a vossa clemência, espera-se tudo da vossa generosidade. ${ }^{64}$

Era como se ecoassem nos ouvidos do autor do artigo os versos escritos, no século XII, pelo monge Hélinand de Froidmont:

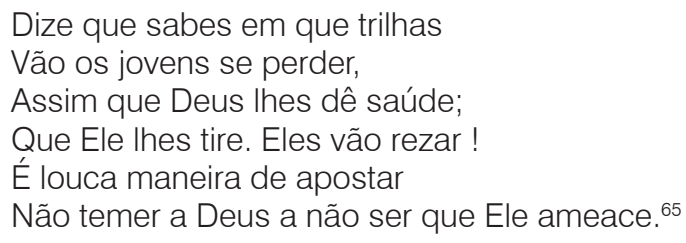

Desta forma, durante a gripe espanhola no início do século XX, período em que a ciência bacteriológica anunciava ter os meios para, de forma parcial mas contínua, desvendar e acabar com os males que afligiam o corpo humano, muitos brasileiros apavorados se prontificaram a compartilhar com seus conterrâneos seus eficientes 'remédios caseiros', e a suplicar pela intercessão dos santos e pela misercórdia divina pelo fim da epidemia. Este medo, que impulsionou a solidariedade e a fé, tanto quanto provocou discriminação, excesso e indiferença, expressou no Novecentos o pavor multifacetado que, invariavelmente, acomete os homens frente ao "mal desconhecido"66 representado pelas catástrofes epidêmicas e, também, atualizou a busca ancestral do ser humano pela explicação definitiva para a existência das enfermidades que o afligem, resposta que nunca foi, ou será, oferecida por nenhum saber médico, e que só a fé, a possibilidade do castigo e do perdão divino, pode proporcionar aos que creem.

64 A Gazeta, São Paulo, n.3.840, p.2, 31 out. 1918

65 FROIDMONT, Hélinand de. Os versos da morte. São Paulo: Ateliê, 1996, p.19.

66 Veja: DUBY, Georges. Ano 1000 ano 2000: na pista de nossos medos, p.80. 